\title{
Malnutrition in school children in an urban-rural region of the extreme South of São Paulo city
}

\author{
Desnutrição em escolares em região urbano-rural do extremo sul do município de São Paulo
}

\author{
Marcela Maria Pandolfi ${ }^{1}$, Fabio Sandrini ${ }^{1}$, Maurício Rocco de Oliveira ${ }^{1}$, Jane de Eston Armond ${ }^{1}$, Ana Cristina Ribeiro \\ Zöllner $^{1}$, Yara Juliano ${ }^{1}$, Patrícia Colombo de Souza ${ }^{1}$
}

\begin{abstract}
Objective: To evaluate the persistence of nutritional deficit in a sample of schoolchildren. Methods: A cross-sectional study of 1,761 schoolchildren between 6 and 10 years from 3 schools. They were assessed by $\mathrm{Z}$ scores of weight for height and height for age, according to the World Health Organization. The variables studied were gender, age, grade and school year. The $\chi^{2}$ test was used to relate the nutritional deficit with the variables. Results: Of all children $8.5 \%$ were malnourished according to the weight for height $Z$ score, $21.6 \%$, according to height for age. The analysis of the weight for height $Z$ score revealed that $59.7 \%$ were male and $40.3 \%$ female. The mean age was 8.9 years. As to the Z score of height for age, $53.9 \%$ were males and $46.1 \%$ females. The risk of malnutrition was higher among boys: $59.7 \%$ for the weight for height index and $53.9 \%$ for height for age. There was no statistical difference between schools, gender and school year. As to nutritional status, school period ( $p<0.0001)$ and students' grade ( $p=0.0105)$, we observed statistical significance. Conclusion: Malnutrition still persists among the low-income population and males had a higher percentage of malnutrition. Nutritional evaluation of students is an extremely important tool for understanding the dynamics of child nutrition and development.
\end{abstract}

Keywords: Protein-energy malnutrition; Nutritional status; Nutritional assessment; Child nutrition

\section{RESUMO}

Objetivo: Verificar a persistência do déficit nutricional em amostra de escolares. Métodos: Estudo transversal com 1.761 escolares de 6 a 10 anos provenientes de 3 escolas de ensino fundamental. Foram avaliados pelos escores $Z$ de peso/estatura e estatura/idade, segundo a Organização Mundial da Saúde. As variáveis estudadas foram: gênero, idade, série e período escolar. 0 teste do $\chi^{2}$ relacionou
0 déficit nutricional com as variáveis. Resultados: Segundo o escore $Z$ de peso/estatura 8,5\% eram desnutridas; $21,6 \%$ de acordo com estatura/idade. $A$ análise do escore $Z$ de peso/estatura revelou que $59,7 \%$ eram meninos e $40,3 \%$ meninas. A média de idade foi de 8,9 anos. Quanto ao escore $Z$ de estatura/idade 53,9\% eram do gênero masculino e 46, $1 \%$ do gênero feminino. 0 risco de desnutrição foi maior entre os meninos: 59,7\% para o índice peso/estatura e 53,9\% para 0 estatura/idade. Não houve diferença estatística na comparação entre as escolas, o gênero e o período escolar. Já entre estado nutricional, período ( $p<0,0001)$ e série dos escolares $(p=0,0105)$, observamos significância. Conclusão: $A$ desnutrição ainda é persistente entre a população de baixa renda e o gênero masculino apresentou maior prevalência. Pode-se considerar que a avaliação nutricional é uma ferramenta de extrema importância para compreensão da dinâmica nutricional de crianças e seu desenvolvimento.

Descritores: Desnutrição proteico-energética; Estado nutricional; Avaliação nutricional; Nutrição da criança

\section{INTRODUCTION}

Childhood malnutrition persists as one of the most important healthcare problems in the current world, due to its magnitude and disastrous consequences for growth, development, and survival of children, related to about $50 \%$ of child mortality world-wide ${ }^{(1)}$. Concerning this issue it might be said that malnutrition is, without a doubt, a latent problem in the Latin American context that affects primarily the population under the age of 5 years ${ }^{(2)}$.

Growth is a dynamic and continuous process, one of the best indicators of a child's health, and it reflects

\footnotetext{
Study carried out at Universidade de Santo Amaro - UNISA, São Paulo (SP), Brazil.

1 Universidade de Santo Amaro - UNISA, São Paulo (SP), Brazil.

Corresponding author: Patrícia Colombo de Souza - Patrícia Colombo de Souza - Rua Professor Enéas de Siqueira Neto, 340 - Jardim das Imbuias - CEP 04829-030 - São Paulo (SP), Brazil -

E-mail: colombo@greco.com.br

Received on: Jul 15, 2011 - Accepted on: Nov 1, 2011

Conflict of interest: none
} 
his/her life conditions in the past and present. When the human being is born, he/she carries a genetic potential for growth which, in order to be reached, will depend on the conditions of life the child is exposed to from conception to adulthood. Growth is influenced by intrinsic (genetic) and extrinsic (environmental) factors, including nutrition, hygiene, and habitation; these may either retard or accelerate development ${ }^{(3,4)}$. Nutrition and growth are intrinsically associated, since children do not fulfill their genetic potential for growth if their basic nutritional needs are not met, leading to stature deficits for their age ${ }^{(5)}$.

The accompaniment of the nutritional situation of children in a country or region is an essential instrument for the assessment of healthcare conditions of the child population ${ }^{(6)}$. Anthropometric measures have been used since the $18^{\text {th }}$ century as an instrument of health evaluation, but it was only less than 40 years ago that they were standardized for the evaluation of the nutritional status of individuals and populations. In this regard, measurements of weight and height are considered highly sensitive for reflecting, particularly during the preschool age, variations in nutritional conditions, and, indirectly, the influence of the social/economic environment. Therefore, anthropometric indices may be considered positive indicators of health, since they enable the assessment of the potential physical development attained ${ }^{(7)}$.

In Brazil, although nutritional inquiries point to a drop in prevalence of malnutrition over the last 30 years $^{(8)}$, the persistence of infectious and parasitic diseases, namely those associated with malnutrition, among the top five causes of death and the occurrence of high hospital mortality rates due to malnutrition, suggest that the role of malnutrition is still vital in statistics of morbidity and mortality for those under the age of 5 years in the country ${ }^{(9-12)}$.

Due to the fact that currently there are fewer severely undernourished children, the importance of the problem has been increasingly minimized to the point of ignoring the existence of the silent epidemic of hidden hunger and malnutrition that is expressed in the number of children with moderate and light starvation, which are less evident ${ }^{(1)}$.

\section{OBJECTIVE}

To evaluate the nutritional status of schoolchildren who attend public schools in the region of Parelheiros, in the southern part of the municipality of São Paulo, in order to detect nutritional alterations as well as associations with gender, grade, level in school, and school period.

\section{METHODS}

This was a cross-sectional study, part of a joint project with the Secretaria Municipal de Saúde e Educação do Município de São Paulo carried out during the months of September to October, 2009, with the objective of investigating the nutritional conditions of children aged 6 to10 years, in a region of urban and rural characteristics, high fecundity rate and urban violence, low human development, social and economic indexes.

The data presented here refer to the group of children from three elementary I schools (Escola Municipal de Ensino Fundamental Manuel Vieira de Queiroz Filho, Escola Municipal de Ensino Fundamental Pedro Geraldo Shunck, and Escola Municipal de Ensino Fundamental Vargem Grande), totalizing 2,173 children. The study included 1,761 children, corresponding to $81 \%$ of the entire sample. The $19 \%$ loss occurred because of absences on the day of the evaluation.

It is interesting that in one of the schools (Escola Municipal de Ensino Fundamental Pedro Geraldo Schunck) there were only two class periods (7 a.m. to 11 a.m. and 3 p.m. to 7 p.m.), whereas the other schools had three (7 a.m. to 11 a.m., 11 a.m. to 3 p.m. and 3 p.m. to 7 p.m.), a fact taken into consideration in the results.

Measurements of weight and height were obtained from each child according to the World Organization of Health (WHO) international protocol ${ }^{(13)}$. They were taken by students of the School of Medicine of Santo Amaro (UNISA), who had been duly trained as to standardization of the techniques.

The anthropometric equipment consisted of a Filizola ${ }^{\circledR}$ platform scale with a capacity for $150 \mathrm{~kg}$ and precision of $100 \mathrm{~g}$. The children were weighed without shoes and wearing light clothing. To measure height, a portable stadiometer with maximal extension of $2 \mathrm{~m}$ was used.

Height over age (H/A) and weight over height $(\mathrm{W} / \mathrm{H})$ were the anthropometric indicators used. The nutritional state was assessed based on the calculation of the $\mathrm{Z}$ scores described above for the means and standard deviation of the reference population of the $\mathrm{WHO}^{(14)}$. To classify malnutrition, the following cut-off points were used. For H/A: $\geq-2$ as risk of malnutrition, and $<-2 \mathrm{Z}$ scores and $\geq-3$ $\mathrm{Z}$ scores as malnutrition. For the $\mathrm{W} / \mathrm{H}$ index, cut-off points were: $\geq-3 \mathrm{Z}$ score and $<-2 \mathrm{Z}$ scores for risk of malnutrition, and $<-3 \mathrm{Z}$-score for malnutrition.

The dependent variable was the measurement of the Z-score separated into $\mathrm{H} / \mathrm{A}$ and $\mathrm{W} / \mathrm{H}$. Additionally, data were correlated with gender, grade 
in school, and class period (7 a.m. to 11 a.m., 11 a.m. to 3 p.m., and 3 p.m. to 7 p.m.).

The databank was analyzed with the Epi-Info program and Epinut ${ }^{(15)}$. The $\chi^{2}$ test was used with a significance level of 0.05 to evaluate the nutritional state and the variables studied ${ }^{(16)}$.

As per Resolution 196/96 of the Ministry of Health, several days before the research was conducted, an information flyer and request for authorization for child participation in the study from the parents or persons responsible were sent to the homes.

The study was approved by the Ethics Committee of the University of Santo Amaro, with Protocol \# 040/2006.

A 19\%-rate of absenteeism among the children and the lack of one class period in one of the schools studied were taken into consideration as possible limiting factors of the study.

\section{RESULTS}

Of the 1,761 children studied, $149(8.5 \%)$ were undernourished, according to the $\mathrm{Z}$ score of $\mathrm{W} / \mathrm{H}$, and $380(21.6 \%)$ according to the $\mathrm{Z}$ score of $\mathrm{H} / \mathrm{A}$.

Analysis of the $\mathrm{Z}$ score of $\mathrm{W} / \mathrm{H}$ showed that $59.7 \%$ were males and $40.3 \%$ were females. The age mean was 8.9 years, with a minimum of 6.9 years and a maximum of 10.3 years.

Analysis of the $\mathrm{Z}$ score of $\mathrm{H} / \mathrm{A}$ showed that $53.9 \%$ were males and $46.1 \%$ were females. The mean age was 9.4 years, with a minimum of 6.8 years and a maximum of 10.2 years.

Table 1 reveals the prevalence of $83.9 \%$ of children at risk of malnutrition, as per the $\mathrm{W} / \mathrm{H} \mathrm{Z}$ score, with no statistical difference among the schools studied. Comparing the nutritional status of the child with gender, $59.7 \%$ of the children at risk are of the male gender. As to grade in school and class period, there was not statistically significant difference.

Considering the $\mathrm{H} / \mathrm{A} \mathrm{Z}$ score, table 2 shows the prevalence of $81.8 \%$ of children at risk of malnutrition, with no statistical difference among the schools studied. Comparing the nutritional status of the children with gender, $53.9 \%$ of the children at risk were males. As to school grade and class period, there was no statistically significant difference.

Analyzing the nutritional condition relative to $\mathrm{Z}$ scores of $\mathrm{W} / \mathrm{H}$ and $\mathrm{H} / \mathrm{A}$ (Table 3 ), we found no statistically significant difference in the comparison among the schools, genders, and class period. On the other hand, in the relationship between the nutritional status and school grade there was statistical significance $(\mathrm{p}=0.0105)$ in this association.
Table 1. Children at risk of malnutrition and malnourished per weight-for-height, enrolled in three municipal primary schools in the Parelheiros region, per gender, grade and period of study

\begin{tabular}{|c|c|c|c|c|c|}
\hline & \multicolumn{2}{|c|}{ Weight/Height } & \multicolumn{2}{|c|}{ Total } & \multirow{2}{*}{$\chi^{2}$ test } \\
\hline & Risk & Malnourished & $\mathbf{n}$ & $\%$ Risk & \\
\hline \multicolumn{6}{|l|}{ Schools } \\
\hline Manuel & 29 & 3 & 32 & 90.7 & \multirow{4}{*}{$p=0.4516$} \\
\hline Schunck & 36 & 9 & 45 & 80.0 & \\
\hline Plínio & 60 & 12 & 72 & 83.3 & \\
\hline Total & 125 & 24 & 149 & 83.9 & \\
\hline \multicolumn{6}{|l|}{ Gender } \\
\hline Male & 73 & 16 & 89 & 58.4 & \multirow{3}{*}{$p=0.5967$} \\
\hline Female & 52 & 8 & 60 & 66.7 & \\
\hline Total & 125 & 24 & 149 & 59.7 & \\
\hline \multicolumn{6}{|l|}{ Grade } \\
\hline $1 \mathrm{st}$ & 46 & 5 & 51 & 90,2 & \multirow{5}{*}{$p=0.3575$} \\
\hline 2nd & 29 & 8 & 37 & 78,4 & \\
\hline $3 r d$ & 25 & 7 & 32 & 78,2 & \\
\hline 4th & 25 & 4 & 29 & 86,2 & \\
\hline Total & 125 & 24 & 149 & 83,9 & \\
\hline \multicolumn{6}{|l|}{ Period } \\
\hline 7 a.m. to 11 a.m. & 40 & 6 & 46 & 86.9 & \multirow{4}{*}{$p=0.1782$} \\
\hline 11 a.m. to 3 p.m. & 42 & 5 & 47 & 89.4 & \\
\hline 3 p.m. to 7 p.m. & 43 & 13 & 56 & 76.8 & \\
\hline Total & 125 & 24 & 149 & 83.9 & \\
\hline
\end{tabular}

Manuel = Escola Municipal de Ensino Fundamental Manuel Vieira de Queiroz Filho; Shunck = Escola Municipal de Ensino Fundamental Padre Geraldo Schunck; Plínio = Escola Municipal de Ensino Fundamental Vargem Grande

Table 2. Children at risk of malnutrition and malnourished per height-for-age, enrolled in three municipal primary schools in the Parelheiros region, per gender, grade and period of study

\begin{tabular}{|c|c|c|c|c|c|}
\hline & \multicolumn{2}{|c|}{ Height/Age } & \multicolumn{2}{|c|}{ Total } & \multirow{2}{*}{$\chi^{2}$ test } \\
\hline & Risk & Malnourished & $\mathbf{n}$ & $\%$ Risk & \\
\hline \multicolumn{6}{|l|}{ Schools } \\
\hline Manuel & 72 & 16 & 88 & 81.8 & \multirow{4}{*}{$p=0.2122$} \\
\hline Schunck & 74 & 10 & 84 & 88.1 & \\
\hline Plínio & 165 & 43 & 208 & 79.3 & \\
\hline Total & 311 & 69 & 380 & 81.8 & \\
\hline \multicolumn{5}{|l|}{ Gender } & \multirow{4}{*}{$p=0.7290$} \\
\hline Male & 166 & 39 & 205 & 53.4 & \\
\hline Female & 145 & 30 & 175 & 56.5 & \\
\hline Total & 311 & 69 & 380 & 53.9 & \\
\hline \multicolumn{5}{|l|}{ Grade } & \\
\hline $1 \mathrm{st}$ & 66 & 20 & 86 & 76.7 & \multirow{5}{*}{$p=0.1181$} \\
\hline 2nd & 77 & 10 & 87 & 88.5 & \\
\hline $3 r d$ & 75 & 13 & 88 & 85.3 & \\
\hline 4th & 93 & 26 & 119 & 75.2 & \\
\hline Total & 311 & 69 & 380 & 81.4 & \\
\hline \multicolumn{6}{|l|}{ Period } \\
\hline 7 a.m. to 11 a.m. & 120 & 26 & 146 & 82.2 & \multirow{4}{*}{$p=0.4404$} \\
\hline 11 a.m. to 3 p.m. & 69 & 20 & 89 & 77.5 & \\
\hline 3 p.m. to 7 p.m. & 122 & 23 & 145 & 84.2 & \\
\hline Total & 311 & 69 & 380 & 81.8 & \\
\hline
\end{tabular}

Manuel = Escola Municipal de Ensino Fundamental Manuel Vieira de Queiroz Filho; Shunck = Escola Municipal de Ensino Fundamental Padre Geraldo Schunck; Plínio = Escola Municipal de Ensino Fundamental Vargem Grande

Table 4 shows the association between malnutrition and the class period. There is a statistically significant difference between the 11 a.m. to 3 p.m. period ( $\mathrm{p}<0.0001$ ) for 
Table 3. Malnourished children per weight-for-height and height-for-age, enrolled in three municipal primary schools in the Parelheiros region, per gender, grade and period of study

\begin{tabular}{|c|c|c|c|c|c|c|c|}
\hline & \multicolumn{2}{|c|}{$\begin{array}{c}\text { Weight-for- } \\
\text { height }\end{array}$} & \multicolumn{2}{|c|}{$\begin{array}{l}\text { Height-for- } \\
\text { age }\end{array}$} & \multicolumn{2}{|c|}{ Total } & \multirow[t]{2}{*}{$\chi^{2}$ test } \\
\hline & $\mathbf{n}$ & $\%$ & $\mathbf{n}$ & $\%$ & $\mathbf{n}$ & $\%$ & \\
\hline \multicolumn{8}{|l|}{ Schools } \\
\hline Manuel & 32 & 21.5 & 88 & 23.2 & 120 & 22.7 & \multirow{4}{*}{$p=0.1466$} \\
\hline Schunck & 45 & 30.2 & 84 & 22.1 & 129 & 24.4 & \\
\hline Plínio & 72 & 48.3 & 208 & 54.7 & 280 & 52.9 & \\
\hline Total & 149 & 100.0 & 380 & 100.0 & 529 & 100.0 & \\
\hline \multicolumn{8}{|l|}{ Gender } \\
\hline Male & 89 & 59.7 & 205 & 53.9 & 294 & 55.6 & \multirow{3}{*}{$p=0.267$} \\
\hline Female & 60 & 40.3 & 175 & 46.1 & 235 & 44.4 & \\
\hline Total & 149 & 100.0 & 380 & 100.0 & 529 & 100.0 & \\
\hline \multicolumn{8}{|l|}{ Grade } \\
\hline $1 \mathrm{st}$ & 51 & 34.2 & 86 & 22.6 & 137 & 25.9 & \multirow{5}{*}{$p=0.0105^{*}$} \\
\hline 2nd & 37 & 24.8 & 87 & 22.9 & 124 & 23.4 & \\
\hline $3 \mathrm{rd}$ & 32 & 21.5 & 88 & 23.2 & 120 & 22.7 & \\
\hline 4th & 29 & 19.5 & 119 & 31.3 & 148 & 28.0 & \\
\hline Total & 149 & 100.0 & 380 & 100.0 & 529 & 100.0 & \\
\hline \multicolumn{8}{|l|}{ Period } \\
\hline 7 a.m. to 11 a.m. & 46 & 30.9 & 146 & 38.4 & 192 & 36.3 & \multirow{4}{*}{$p=0.1086$} \\
\hline 11 a.m. to 3 p.m. & 47 & 31.5 & 89 & 23.4 & 136 & 25.7 & \\
\hline 3 p.m. to 7 p.m. & 56 & 37.6 & 145 & 38.2 & 201 & 38.0 & \\
\hline Total & 149 & 100.0 & 380 & 100.0 & 529 & 100.0 & \\
\hline
\end{tabular}

Manuel = Escola Municipal de Ensino Fundamental Manuel Vieira de Queiroz Filho; Shunck = Escola Municipal de Ensino Fundamental Padre Geraldo Schunck; Plínio = Escola Municipal de Ensino Fundamental Vargem Grande

Table 4. Malnourished children per weight-for-height and height-for-age per grade and period of study

\begin{tabular}{|c|c|c|c|c|c|c|c|c|}
\hline \multirow{3}{*}{ Grade } & \multicolumn{6}{|c|}{ Period P/E } & \multirow{2}{*}{\multicolumn{2}{|c|}{ Total }} \\
\hline & \multicolumn{2}{|c|}{7 a.m. to 11 a.m. } & \multicolumn{2}{|c|}{11 a.m. to 3 p.m. } & \multicolumn{2}{|c|}{3 p.m. to 7 p.m. } & & \\
\hline & $\mathbf{n}$ & $\%$ & $\mathbf{n}$ & $\%$ & n & $\%$ & $\mathbf{n}$ & $\%$ \\
\hline 1 st & 10 & 21.7 & 31 & $66.0^{*}$ & 10 & 17.8 & 51 & 34.2 \\
\hline 2nd & 10 & 21.7 & 7 & 14.9 & 20 & 35.7 & 37 & 24.8 \\
\hline $3 r d$ & 4 & 8.7 & 9 & 19.1 & 19 & 33.9 & 32 & 21.5 \\
\hline 4th & 22 & 47.9 & 0 & 0 & 7 & 12.5 & 29 & 19.5 \\
\hline \multirow[t]{2}{*}{ Total } & 46 & 100 & 47 & 100 & 56 & 100 & 149 & 100.0 \\
\hline & \multicolumn{6}{|c|}{ Period E/I } & \multirow{2}{*}{\multicolumn{2}{|c|}{ Total }} \\
\hline \multirow[t]{2}{*}{ Grade } & \multicolumn{2}{|c|}{7 a.m. to 11 a.m. } & \multicolumn{2}{|c|}{11 a.m. to 3 p.m. } & \multicolumn{2}{|c|}{3 p.m. to 7 p.m. } & & \\
\hline & n & $\%$ & $\mathbf{n}$ & $\%$ & n & $\%$ & n & $\%$ \\
\hline 1 st & 25 & 17.8 & 39 & 43.8 & 22 & 15.2 & 86 & 22.6 \\
\hline 2nd & 14 & 9.6 & 9 & 10.2 & 64 & 44.1 & 87 & 22.9 \\
\hline $3 r d$ & 8 & 5.5 & 40 & 44.9 & 40 & 27.6 & 88 & 23.2 \\
\hline 4th & 99 & $67.1^{* *}$ & 1 & 1.12 & 19 & 13.1 & 119 & 31.3 \\
\hline Total & 146 & 100 & 89 & 100 & 145 & 100 & 380 & 100.0 \\
\hline
\end{tabular}

children with a nutritional deficit, as per the $\mathrm{W} / \mathrm{H}$ index, and the 7 a.m. to 11 a.m. period ( $\mathrm{p}<0.0001)$ for children with nutritional deficits, as the $\mathrm{H} / \mathrm{A}$ index.

\section{DISCUSSION}

Despite the improvement of nutritional conditions of children in Brazil, malnutrition has occurred in a very unequal manner, and the problem is even more serious in the poorest regions of the country, and in the pockets of poverty within the large cities ${ }^{(17)}$.

In developing countries, it is estimated that the prevalence of malnutrition in children aged up to 60 months is $8 \%$ for weight-for-height, $32 \%$ for height/age, and $27 \%$ for weight-for-age ${ }^{(18)}$.

A study carried out by Burlandy ${ }^{(19)}$ with school children between 7 and 10 years of age identified a total of $13.2 \%$ who presented with malnutrition seen by height deficit (13.8 and $12.5 \%$ of the boys and girls, respectively). The highest prevalence occurred, as expected, in the rural Northeast $(21.9 \%)$, and the lowest, in the rural Southeast $(8.4 \%)$. Prevalence in the rural area is still superior to that of the urban area. Malnutrition with a weight deficit was low, and it can be said that in truth there apparently was no malnutrition, since the values of $\mathrm{Z}<-2$ are close to what is expected for a healthy population (approximately $2.5 \%$ ).

In the states of Ceará, Paraíba, and Piauí state-wide surveys were conducted for height relative to age. In the state of Paraíba, the prevalence to the entire state was $14.5 \%$, with a height deficit of $17.86 \%$ in the rural area and $11.87 \%$ in the urban area ${ }^{(20)}$.

The prevalence of the risk of malnutrition and malnutrition in this study was relatively high. As to the association between gender and malnutrition, there was a predominance in the male gender, although without statistical significance, with is in agreement with the results presented in other investigations.

Specifically related to the age bracket of the schoolchildren, nation-wide analyses on the nutritional status of this segment are scarce. Studies this size normally focus on the situation of children under the age of 5 years or schoolchildren from specific regions/ cities of the country. For example, a representative sample of schoolchildren of the municipality of Rio de Janeiro, Anjos et al. ${ }^{(21)}$ found very low prevalence rates of malnutrition reflected in height deficit (1.9 and 2.8\% for girls and boys up to ten years of age, respectively). Analysis of data from the National Research on Health and Nutrition indicated a $12.9 \%$ percentage of malnutrition with height deficit in Brazilian children aged 6 to 10 years, and the highest prevalence rates were found in the Northeast and North regions ${ }^{(22)}$.

The cutoff point recommended internationally for classifying a child as undernourished (Z-score under 2 standard deviations, compared to the mean national reference value $)^{(23)}$ has been used in population studies, identifying prevalence and tendencies of moderate to severe malnutrition.

In Brazil, between 1975 and 1989, as a result of economic gains and of the great expansion of healthcare 
programs, the prevalence of child malnutrition was reduced by about $60 \%$, representing more than 1 million children. However, the most common form of malnutrition, the height deficit relative to age, is concentrated in the poorest regions of the country, showing that the problem is not totally controlled ${ }^{(1,2)}$.

It is estimated that $38.1 \%$ of children under the age of 5 years who live in developing countries suffer severe growth compromise (stunting) and that $9.0 \%$ present with extreme thinness (wasting). These conditions are associated with other signs of damage, an increase in incidence and severity of infectious diseases, increased rates of child mortality, psychomotor development retardation, difficulties in school performance, and decreased height and productive capacity in adult life ${ }^{(24,25)}$.

Grave malnutrition may leave two important sequelae: one related to height, and the other to mental development. Height may develop if the child does not experience recurring infections and receives an adequate diet, but mental development alterations may be serious and permanent; depending on the degree of malnutrition, these lesions are responsible for neurological and psychomotor development delays in children, although this retardation may be recovered if the child receives an adequate diet and is in a stimulating sociocultural environment ${ }^{(26)}$.

As to the child's school grade, the fourth grade has the children with the highest school age and displays the worst results as to malnutrition, as per the $\mathrm{H} / \mathrm{A} \mathrm{Z}$-score. As to malnutrition according to the $\mathrm{W} / \mathrm{H} \mathrm{Z}$-score, the first grade was the most affected, and this difference was statistically significant. This shows that there is still a large percentage of school-aged children with stature deficits incorrigible by treatments.

The intermediate class period (11 a.m. to 3 p.m.) was created by the Prefecture of São Paulo in the 1970s to serve high demand areas where there were no vacancies in the morning and afternoon classes. For this reason, the third class period was squeezed in between the other two, with a class load limited to 4 daily hours imposed by law. This temporary solution continues until today ${ }^{(27)}$.

When analyzing the class period of the children in the study, we noted that the 11 a.m. to 3 p.m. period was statistically significant for children with nutritional deficits as per the $\mathrm{W} / \mathrm{H}$ index, and the 7 a.m. to 1 a.m. period for the children with nutritional deficits as per the H/A index. Since this period coincides with the lunch hour, it is called the "hunger period", a fact that can hinder school performance and meal times. This can have repercussions in the child's nutritional status, in this case, primarily for acute malnutrition, due to the inadequate timing of the meal.

The nutritional evaluation of children by means of nutritional monitoring using repeated collections of anthropometric data allows orientation for planning, executing, and evaluation healthcare programs in a given population ${ }^{(4,28,29)}$.

Due to the fact that the nutritional status increases the development of diseases and interferes in a child's growth and development, early nutritional evaluations are necessary in the child population, which can reveal the magnitude of the current deficiency and the determining factors for the occurrence of damage ${ }^{(30)}$.

\section{CONCLUSION}

Malnutrition is still persistent among the low-income population, the irreparable form of nutritional deficit is greater in absolute numbers, and males presented with the higher percentage of cases. Based on the analysis made in the Parelheiros region, one can consider that the nutritional assessment of school children - especially the performance of the anthropometric technique is an extremely important tool for understanding the nutritional dynamics of children and their development, thus helping to formulate healthcare policies and more effective actions to eradicate this problem persistent for so long in the history of healthcare in Brazil. We suggest the continuity of this work in other regions of the municipality.

\section{REFERENCES}

1. Monte CM. Desnutrição: um desafio secular à nutrição infantil. J Pediatr (Rio J). 2000;76(Suppl 3):285-97.

2. Martins IS, Marinho SP, Oliveira DC, Araújo EA. Pobreza, desnutrição e obesidade: inter-relação de estados nutricionais de indivíduos de uma mesma família. Cienc Saúde Coletiva. 2007;12(6):1553-64.

3. Romani SA, de Lira PI. Fatores determinantes do crescimento infantil. Rev. Bras. Saúde Mater Infant. 2004;4(1):15-23.

4. Neves OM, Brasil ALD, Brasil LM, Taddei JA. Antropometria de escolares ao ingresso no ensino fundamental na cidade de Belém, Pará, 2001. Rev Bras Saúde Matern Infant. 2006;6(1):39-46.

5. Sichieri R, Taddei JA, Everhart JE. Influence of parental height and sociodemographic factors on adolescent height in Brazil. J Adolesc Health. 2000;26(6):414-9

6. Silva KS, Lopes AS, Silva FM. Sensibilidade e especificidade de diferentes critérios de classificação do excesso de peso em escolares de João Pessoa, Paraíba, Brasil. Rev Nutr. 2010;23(1):27-35.

7. Fernandes IT, Gallo PR, Advíncula A0. Avaliação antropométrica de préescolares do município de Mogi-Guaçú, São Paulo: subsídio para políticas públicas de saúde. Rev Bras Saúde Matern Infant. 2006;6(2):217-22.

8. Monteiro CA. A dimensão da pobreza, da desnutrição e da fome no Brasil. Est. Avançado. 2003;17(1):7-20.

9. Victora CG, César JA. Saúde materno-infantil no Brasil: padrões de morbimortalidade e possíveis intervenções. In: Rouquayrol MZ, Almeida Filho N. Epidemiologia e saúde. Rio de Janeiro: Medsi; 2003. p. 415-68.

10. Falbo AR, Alves JG. Desnutrição grave: alguns aspectos clínicos e epidemiológicos de crianças hospitalizadas no Instituto Materno Infantil de Pernambuco (IMIP), Brasil. Cad. Saúde Pública. 2002;18:1473-7. 
11. Monteiro CA, Benicio MH, Konno SC, Silva AC, Lima AL, Conde WL. Causes for the decline in child under-nutrition in Brazil, 1996-2007. Rev Saúde Pública. 2009;43(1):1-8.

12. Lima AL, Silva AC, Konno SC, Conde WL, Benicio MH, Monteiro CA. Causas do declínio acelerado da desnutrição infantil no Nordeste do Brasil (1986-19962006). Rev Saúde Pública. 2010;44(1):17-27.

13. Organización Mundial de la Salud. El estado físico: uso e interpretación de la antropometría: informe de um Comité de Expertos de la OMS. Ginebra; OMS; 1995. (Serie de Informes Técnicos, 854).

14. de Onis M, Garza C, Victora CG, Maharaj K, Bhan MK, Norum KR.The WHO multicentre growth reference study (MGRS): Rationale, planning, and implementation. Food Nutr Bull. 2004:25(1 Suppl. 1):S1- S45.

15. Dean AG, Dean JA, Coulombier D, Brendel KA, Smith DC, Burton HA, et al. Epi Info, version 6.04: a word processing database and statistics program for a epidemiology on microcomputers. Atlanta: Centers for Disease Control and Prevention; 1996.

16. Siegel S, Castellan NJ Jr. Estatística não paramétrica para ciências do comportamento. 2a ed. Artmed. Porto Alegre. 2006.

17. Santos RB, Martins PA, Sawaya AL. Estado nutricional, condições socioeconômicas, ambientais e de saúde de crianças morados em cortiços e favela. Rev Nutr. 2008;21(6):671-81.

18. Goulart RM, Junior IF, Souza MF. Recuperação nutricional de crianças desnutridas e em risco nutricional em programa de suplementação alimentar no Município de Mogi das Cruzes, São Paulo, Brasil. Cad Saúde Pública. 2007;23(1):147-56.

19. Burlandy L, Anjos LA. Acesso à alimentação escolar e estado nutricional de escolares no Nordeste e Sudeste do Brasil, 1997. Cad Saúde Pública. 2007;23(5):1217-26.

20. Carvalho AT, Costa MJ, Ferreira LO, Batista Filho M. Cartografia do retardo estatural em escolares do Estado da Paraíba, Brasil. Rev Saúde Pública. 2000;34(1):3-8.
21. Anjos LA, Castro IR, Engstrom EM, Azevedo AMF. Crescimento e estado nutricional em amostra probabilística de escolares no Município do Rio de Janeiro, 1999. Cad Saúde Pública. 2003;19 Suppl 1:S171-9.

22. Engstrom EM, Anjos LA. Déficit estatural nas crianças brasileiras: relações com condições sócio-ambientais e estado nutricional materno. Cad Saúde Pública. 1999;15(3):559-67.

23. Blössner M, Onis M. Malnutrition: quantifying the health impact at national and local levels. Geneve: WHO; 2005. (Environmental Burden of Disease Series, $\left.n^{0} 12\right)$.

24. Monteiro CA, Conde WL. Tendência secular da desnutrição e da obesidade na infância na cidade de São Paulo (1974-1996). Rev Saúde Pública. 2000; 34(6 Supl):52-61.

25. Ministério da Saúde. Sistema de Vigilância Alimentar e Nutricional (SISVAN): Orientações básicas para coleta, processamento, análise de dados e informação em serviços de saúde. Brasília: Ministério da Saúde. 2008.

26. Muradas MR, Carvalho SD. Fatores que influenciam a desnutrição infantil em um centro de saúde do município de Campinas (SP). Cienc Cuid Saúde. 2008; 7(1):53-8.

27. Ministério do Planejamento, Orçamento e Gestão. 0 turno da fome. Porta ClippingMP de 08/01/2010. [Internet] [citado 2010 Mar 1] Disponível em: https://conteudoclippingmp.planejamento.gov.br.

28. Martino HS, Ferreira AC, Pereira CN, Silva RR. Avaliação antropométrica e análise dietética de pré-escolares em centros educacionais municipais no Sul de Minas Gerais. Cienc Saúde Coletiva. 2010;15(2):551-558.

29. Tuma RC, Costa TH, Schmitz BA. Avaliação antropométrica e dietética de préescolares em três creches de Brasília, Distrito Federal. Rev Bras Saúde Matern Infant. 2005;5(4):419-28.

30. Castro TG, Novaes JF, Silva MR, Costa NR, Franceschini SC, Tinoco AL, et al. Caracterização do consumo alimentar, ambiente socioeconômico e estado nutricional de pré-escolares de creches municipais. Rev Nutr. 2005;18(3):321- 30. 